\title{
Information culture of a teacher as a factor of the development of the city human resources
}

\author{
Svetlana Sotnikova ${ }^{1 *}$, Yuliya Semenova ${ }^{1}$, and Nadezhda Zabelina ${ }^{1}$ \\ ${ }^{1}$ Kursk State University, Department of Theory and Methods of Teaching Foreign Languages, Kursk, \\ Russia
}

\begin{abstract}
The prerequisite for the study has been the need to develop a model for the formation of information culture for bachelors as future foreign language teachers, taking into account the requirements of the contemporary labor market of pedagogical specialties in the framework of developing the urban human resources potential. The purpose of the research is to study the problem in the context of training qualified humanitarian personnel who can meet professional challenges and be competitive candidates in the educational market of a contemporary city. The article discusses the concept of information culture and describes its functions and structural components. The research methods used include a conversation with teachers and students, a survey of teachers and students on key issues, generalization of experience in organizing work with students in the framework of contact and independent work at school and university, as well as experimental training. The authors describe the model of information culture formation in bachelors specialized in the humanities, the means of information culture formation, and identify the levels of its formedness. The formedness level of a bachelor's information culture is proposed to be evaluated according to motivational, substantive, professional and technological, and evaluative-performative criteria. The authors cover in detail the content of the information culture forming process of future foreign language teachers. Research results and novelty are presented by the described model of information culture formation in bachelors as future teachers of a foreign language reflected in the special authorial course. The article offers sample topics and control tasks on a developed course. The article may be of interest to specialists in the field of teacher education, e-learning, and the design of information and educational environments in the humanitarian sector of a contemporary city. The proposed model can be used in the system of professional development of foreign language teachers.
\end{abstract}

Keywords: urban educational environment, personnel training, information culture.

\footnotetext{
${ }^{*}$ Corresponding author: svetlana-s-sotnikova@yandex.ru
} 


\section{Introduction}

The educational space of a contemporary city implies the interaction of all subjects involved in educational processes, both through personal contacts and indirectly through various information resources. The urban information environment is well developed and abounds in various forms of information presentation. To carry out effective professional activities in the current state of the city's educational environment, a teacher must have a fairly wide range of competencies. The classical requirements for a teacher, such as knowledge of native and foreign languages, psychology, and pedagogy, are supplemented by the concept of information culture which is considered in the works of many scientists, such as V.P. Bespalko, A.M. Korotkov, M.Z. Biboletova, V.P. Sizikov, N.N. Chernenko, E.S. Polat, A.V. Khutorsky, and others.

The formation of information culture in bachelor as a future foreign language teacher will be more effective if:

1. highlighting the general status of information technologies development in the training process which can be used for pedagogical purposes, as well as the prospects for the development of the urban educational environment;

2. using various sources and forms of information presented in the learning process;

3. building learning process based on the developed model for the formation of information culture in bachelor as a future teacher in the open educational space of the city [1-4].

In the reference literature, information culture is most often understood as the presence of special knowledge, skills, and abilities to work effectively with information that provides a variety of available ways to search and use the necessary data ranged from working with the library database and possessing computer literacy to working with the Internet [5]. According to N.N. Elistratova, information culture is a part of the culture of a community or individual which includes awareness of the value of information and the ability to work with it [6]. Among the main functions of teachers' information culture, one may distinguish axiological, concentrating, developing, and regulating features. At that, motivational-value, cognitive, technological (instrumental-activity), and communicative components make up the structure of the teacher's information culture [7].

\section{Methods}

When working with the article, the authors used analysis of scientific literature, observation of the educational process, conversation with teachers and students, interviews, questionnaires of teachers and students on key issues, a generalization of experience in organizing work with students in the framework of contact and independent work at school and university, as well as experimental training.

\section{Results}

The teacher's information culture formation model is based on systemic, activity, and competence approaches. The systemic approach implies that the research object and subject are considered as a system, a set of interrelated elements. The activity-based approach is used to improve the effectiveness of the model so that students can acquire skills that contribute to the formation of an information culture independently during practical exercises. The competency-based approach implies the development of students' ability to independently solve problems that arise in the course of professional and educational activities [8]. 
The proposed model is based on the following didactic principles: professional orientation, differentiation, and individualization, scientific character, communicativeness, increasing the proportion of students' self-sufficiency, novelty, and strength.

To form information culture in a bachelor as a future foreign language teacher, it is advisable to choose the following means: information and communication technologies, which include software (application support software) and hardware as main components $[9,10]$.

Considering the problem of information culture formation in bachelors as the future teachers in the course of their learning, as well as taking into account the above analysis of this concept, the authors consider it appropriate to assess the level of information culture completeness of bachelors as the future teachers according to the following criteria:

- motivational criterion takes into account the desire to implement the teacher's capabilities, namely, creating their authorial digital educational resources, developing methodology, participating in project activities, having skills to work with the open educational space of a contemporary city and the Internet;

- substantive criterion takes into account the possession of technical, system, and software components, as well as methodological qualities, namely, the presence of professional and general cultural erudition, understanding the value of information activities, integrating the teacher's activities with these values, using digital educational resources of a contemporary city for self-education;

- the professional and technological criterion is applied to assess the set of skills and abilities to use information and communication technology (ICT) in professional activities (both for solving current pedagogical tasks and ensuring information interaction within the team in an educational organization, as well as in the humanitarian realm of the city in general);

- evaluative-performative criterion is used for checking and/or self-checking the level of knowledge, skills, and abilities; the presence of achievements in both pedagogical and informational activities; participating in joint projects with peers from other fields of activity $[11,12]$.

Considering these criteria indicators, one can distinguish three levels of formedness of the teacher's information culture, namely, low, medium, and high.

The model is implemented in certain pedagogical conditions, which include:

1. proper substantiation of educational activities;

2. professionally-oriented content of learning material;

3. development of the student's creative potential.

The implementation of the model should result in a specialist, who:

- has theoretical knowledge in the field of ICT, sufficient for the successful implementation of pedagogical activities, and can work with data in the contemporary urban educational space;

- possesses knowledge at the reproductive level, i.e. can reproduce the information received not only in the course of training but also when accessing the information resources of the city;

- knows how to search and process data using ICT, as well as how to solve professional problems using ICT;

- can independently assess current situation, create an action plan to perform new tasks, and achieve the corresponding goal, as well as offer nonconventional ways to solve problems [13-16]. 


\section{Discussion}

Extensive Table 1 shows a model reflecting the information culture formation in bachelor as a future foreign language teacher.

Table 1. Model of information culture formation in bachelor as a future foreign language teacher.

Goal: to form information culture in bachelor as a future foreign language teacher Approaches: systemic, learner-centered, activity-based, and competence-based

Principles: professional orientation, differentiation, and individualization, scientific character, communicativeness, increasing the proportion of students' self-sufficiency, novelty, and strength

\section{Content of the information culture forming process in a bachelor as a future foreign language teacher}

\begin{tabular}{|c|c|c|c|}
\hline $\begin{array}{l}\text { Cognitive } \\
\text { aspect }\end{array}$ & $\begin{array}{c}\text { Developing } \\
\text { aspect }\end{array}$ & $\begin{array}{c}\text { Educational } \\
\text { aspect }\end{array}$ & $\begin{array}{c}\text { Upbringing } \\
\text { aspect }\end{array}$ \\
\hline \multirow[t]{4}{*}{$\begin{array}{l}\text { Expanding professional } \\
\text { horizons based on } \\
\text { comparative analysis of } \\
\text { didactic material and } \\
\text { its mastering }\end{array}$} & \multirow[t]{2}{*}{$\begin{array}{l}\text { Developing flexible } \\
\text { pedagogical thinking }\end{array}$} & $\begin{array}{c}\text { Acquiring } \\
\text { knowledge about } \\
\text { approaches to the } \\
\text { information culture } \\
\text { formation }\end{array}$ & $\begin{array}{l}\text { Mastering the value } \\
\text { orientations of a } \\
\text { foreign language } \\
\text { teacher }\end{array}$ \\
\hline & & $\begin{array}{c}\text { Developing } \\
\text { information } \\
\text { management skills }\end{array}$ & $\begin{array}{l}\text { Educating a person } \\
\text { with a global mindset }\end{array}$ \\
\hline & \multirow[t]{2}{*}{$\begin{array}{c}\text { Developing } \\
\text { pedagogical } \\
\text { motivation }\end{array}$} & \multirow{2}{*}{$\begin{array}{l}\text { Mastering the } \\
\text { experience of using } \\
\text { multimedia } \\
\text { technologies in the } \\
\text { educational process }\end{array}$} & $\begin{array}{l}\text { Training pedagogical } \\
\text { responsibility }\end{array}$ \\
\hline & & & Educating tolerance \\
\hline
\end{tabular}

Means of forming information culture (ICT)

Software component: general and special purpose application software

Hardware component: studying seats equipped for

\section{Pedagogical conditions} effective training

\begin{tabular}{|c|c|c|c|c|c|}
\hline \multicolumn{6}{|c|}{ Pedagogical conditions } \\
\hline \multicolumn{2}{|c|}{$\begin{array}{c}\text { Motivating educational } \\
\text { activities }\end{array}$} & \multicolumn{2}{|c|}{$\begin{array}{l}\text { Developing students ' creative } \\
\text { potential }\end{array}$} & \multicolumn{2}{|c|}{$\begin{array}{c}\text { Professionally-oriented content } \\
\text { of educational material }\end{array}$} \\
\hline \multicolumn{6}{|c|}{ Information culture formedness criteria } \\
\hline Motivational & \multicolumn{2}{|c|}{ Substantive } & \multicolumn{2}{|c|}{$\begin{array}{l}\text { Professional and } \\
\text { technological }\end{array}$} & $\begin{array}{l}\text { Evaluative- } \\
\text { performative }\end{array}$ \\
\hline $\begin{array}{c}\text { The desire to } \\
\text { implement their } \\
\text { own } \\
\text { capabilities }\end{array}$ & \multicolumn{2}{|c|}{$\begin{array}{l}\text { Technical, software, } \\
\text { system-based, and } \\
\text { methodological } \\
\text { components }\end{array}$} & \multicolumn{2}{|c|}{$\begin{array}{l}\text { Set of skills and abilities } \\
\text { to apply ICT in } \\
\text { professional activities }\end{array}$} & $\begin{array}{l}\text { Diagnostics } \\
\text { (self-diagnosis) } \\
\text { of knowledge, skills, } \\
\text { and abilities }\end{array}$ \\
\hline \multicolumn{6}{|c|}{ Levels of information culture formedness } \\
\hline \multicolumn{2}{|l|}{ Low } & \multicolumn{2}{|c|}{ Medium } & \multicolumn{2}{|r|}{ High } \\
\hline \multicolumn{6}{|c|}{ Information culture presence indicators } \\
\hline $\begin{array}{l}\text { Fragmentary } \\
\text { theoretical } \\
\text { knowledge and } \\
\text { skills of }\end{array}$ & \multicolumn{2}{|c|}{$\begin{array}{l}\text { Possessing } \\
\text { knowledge at the } \\
\text { reproductive level } \\
\text { (reproducing }\end{array}$} & \multicolumn{2}{|c|}{$\begin{array}{l}\text { Using data search and } \\
\text { ICT-based processing } \\
\text { tools; } \\
\text { solving professional }\end{array}$} & $\begin{array}{l}\text { Ability to independently } \\
\text { assess current situation, } \\
\text { create an action plan to } \\
\text { perform new tasks and }\end{array}$ \\
\hline
\end{tabular}




\begin{tabular}{|c|c|c|c|}
\hline $\begin{array}{c}\text { working with } \\
\text { data }\end{array}$ & $\begin{array}{c}\text { information received, } \\
\text { operations and } \\
\text { actions learned in the } \\
\text { learning process) }\end{array}$ & tasks using ICT & $\begin{array}{c}\text { achieve the corresponding } \\
\text { goal; } \\
\text { ability to offer } \\
\text { nonconventional ways to } \\
\text { solve problems }\end{array}$ \\
\hline
\end{tabular}

The proposed model was tested in the framework of a training course to form information culture in bachelors as future foreign language teachers. The training course is designed for 10 academic hours and contains information and tasks on seven key topics:

1. General information about computerization, the Internet, the concepts of "Information culture", "Digital educational resource", and "Electronic educational resource".

2. Safe work on the Internet. The concepts of "Computer virus", "Antivirus", precautions when working on a computer and searching for information to prepare for classes.

3. Searching for information on the Internet. Using search engines. Bibliographic resources on the Internet. Familiarizing with the city's information resources.

4. Working with office programs using the Microsoft Office Suite as an example.

5. Working with Microsoft PowerPoint. Creating interactive presentations, games, and tests based on learning material.

6. Creating, editing, and maintaining a teacher's personal website using the Website Builder as an example.

7. Distance learning. Concepts, rules, and aspects. Opportunities for an application.

Below is a brief description of one chapter of the course, namely, General information about computerization, the Internet, the concepts of "Information culture", "Digital educational resource", and "Electronic educational resource".

This section is designed as the introductory topic of the course. Its purpose is to familiarize the reader with the main concepts that will be used during the course, as well as the chronology in the development of modern computer technologies, focusing in more detail on the last decade, as well as giving the most likely projected development of computer technologies.

The topic includes the following issues:

1. The emergence of the first computer networks;

2. The File Transfer Protocol, WorldWideWeb;

3. Computerization of education;

4. Mobile platforms: history and prospects of use;

5. Control tasks.

Table 2. Final tasks for assessing the level of formedness of the bachelor's information culture after studying the course.

\begin{tabular}{|c|c|}
\hline Criterion & Tasks \\
\hline Motivational & $\begin{array}{l}\text { 1. How often would you like to use the digital educational resource } \\
\text { (DER) in your classes? } \\
\text { 2. Will you create DER customized for your personal needs? }\end{array}$ \\
\hline Substantive & $\begin{array}{l}\text { 1. Is your university equipped with computers? } \\
\text { 2. Do you have a ready-to-implement methodological program using } \\
\text { ICT? }\end{array}$ \\
\hline $\begin{array}{c}\text { Professional and } \\
\text { technological }\end{array}$ & Checking the portfolio of tasks completed during the course \\
\hline $\begin{array}{l}\text { Evaluative- } \\
\text { performative }\end{array}$ & $\begin{array}{l}\text { 1. Tell us about bibliographic resources on the Internet; } \\
\text { 2. How to create an interactive presentation in PowerPoint? } \\
\text { 3. What should be the professional website of a teacher? } \\
\text { 4. }\end{array}$ \\
\hline
\end{tabular}




\section{Conclusion}

The developed model can be recommended for use in the preparation of training courses or programs aimed at the formation of the teacher's information culture in the urban educational space.

\section{References}

1. N. Gendina, Integrating the Personal Information Culture Concept and the Idea of Media and Information Literacy Offered in the UNESCO Curriculum for Teachers: Experiences of Russia and Uzbekistan, in Information Literacy: Key to an Inclusive Society. ECIL 2016. Communications in Computer and Information Science, 676 (Springer, Cham, 2016)

2. I.A. Bredikhina, Pedagogical education in Russia, 9, 77-81 (2015)

3. C.W. Choo, International Journal of Information Management, 33(5), 775-779 (2013)

4. L.A. Mosunova, Sci. Tech. Inf. Proc. 45, 128-134 (2018)

5. Dictionaries and encyclopedias on Academic. Accessed on: December 20, 2020. [Online]. Available: http://dic.academic.ru

6. R.V. Belyayev, Ye.I. Grigoriyeva, Bulletin of the Moscow State University of Culture and Arts, 2 (70), 90-96 (2016)

7. N.I. Gendina, Bulletin of the Kemerovo State University of Culture and Arts, 42, $13-$ 19 (2018)

8. U.I. Kopzhasarova, M.M. Kubeeva, Scientific Review. Pedagogical science, 2, 65-69 (2017)

9. Ya.A. Vagramenko, A.A. Rusakov, Educational technologies and society, 20(4), 384390 (2017)

10. T. Brunfaut, C. Clapham, Assessment and Testing, in Routhledge Encyclopedia of Language Teaching and Learning, 52-59 (Routhledge, New York, 2013)

11. N.D. Galskova, A.P. Vasilevich, N.F. Koryakovtseva, N.V. Akimova, Osnovy metodiki obucheniya inostrannym yazykam [Fundamentals of methods of teaching foreign languages] (KNORUS, Moscow, 2018)

12. A.A. Khrulev, Formirovaniye informatsionnoy kul'tury budushchikh uchiteley angliyskogo yazyka [Formation of information culture of future English language teachers], Thesis (Yalta, 2019)

13. N. Almazova, D. Barinova, O. Ipatov, Forming of Information Culture With Tools of Electronic Didactic Materials, in Proceedings of the 29th DAAAM International Symposium, 587-593 (DAAAM International, Vienna, 2018)

14. P.A. Iannuzzi, From information overload to information savvy. Presentation at Keynote Address, Seattle, WA. (2020). Accessed on: December 20, 2020. [Online]. Available: https://digitalscholarship.unlv.edu/libfacpresentation/59

15. S. Virkus, V. Kirinić, N. Begičević Ređep, The Role of E-Learning and Information Culture in Educational Institutions in Transforming European Education, in Educational Leadership, Improvement and Change. Palgrave Studies on Leadership and Learning in Teacher Education (Palgrave Pivot, Cham, 2020)

16. T. Wright, Records Management Journal, 23(1), 14-36 (2013) 